\section{Immunohistochemical distribution of insulin-, glucagon- and somatostatin- containing cells in the pancreas of Lake Van fish (Alburnus tarichi Güldenstädt, 1814) (Cyprinidae)}

\section{Burak Kaptaner}

Department of Biology, Faculty of Science, University of Van Yuzuncu Yil, Tuşba/Van, Turkey

\section{Abstract}

The Lake Van fish (Alburnus tarichi) is a species that is endemic to Turkey's Lake Van basin. In this study, the regional distribution, volume density, and relative frequency of some pancreatic endocrine cells in Lake Van fish were investigated via immunohistochemistry using specific mammalian antibodies. The pancreatic tissue was observed to be surrounded by adipose tissue, which was adjacent to the gall bladder or extrahepatic bile duct, or dispersed in the adipose tissue ranked among coils of post-esophageal swelling and intestine. The pancreatic endocrine cells were examined, including the islets, exocrine pancreas, and pancreatic ducts. According to the modified aldehyde fuchsin staining and immunohistochemistry, insulin-secreting beta cells were observed to localize throughout the islets. Glucagon immune-reactive (IR) cells were observed to be situated moderately on the islet periphery, and were rarely determined in the islet central region. A small number of somatostatinIR cells were observed in the islet centers and peripheries. Similar distributions of those three endocrine cells were also determined in the secondary islets. Additionally, the endocrine cell percentages did not differ between the primary and secondary islets; insulin-, glucagon- and somatostatin-IR cells comprised approximately $54 \%, 29 \%$, and $11 \%$ of the endocrine cells in the principal islets, whereas they comprised $52 \%, 27 \%$, and $14 \%$ in the secondary islets, respectively. Insulin-, glucagon- and somatostatin-IR cells were also determined among the epithelium and subepithelial connective tissue in the pancreatic ducts or exocrine areas of the pancreas. With this study, the existence, regional distribution, and relative frequency of the insulin-, glucagon- and somatostatin-IR cells were first investigated in the pancreatic tissue of Lake Van fish and the results were discussed.

\section{Introduction}

The pancreas of teleost fish is composed of exocrine and endocrine portions. The exocrine pancreas produces enzymes that are responsible for the digestion of proteins, carbohydrates, lipids, and nucleotides, whereas the endocrine portion synthesizes and releases regulatory peptide hormones into the bloodstream. ${ }^{1,2}$ The endocrine portion has been expressed by different terms in fish in the past, such as the insular or islet tissue, insular or islet organ, endocrine pancreas, Brockmann bodies, Langerhans islets, and principle islets, because it presents in various forms in terms of size, distribution, and its relation to the exocrine pancreas. Thus, it was expressed that the "islet organ" should be used for a fish species' endocrine pancreatic homolog, regardless of arrangement or distribution. In Actinopterygian (ray-finned) fish, which demonstrate a wide variety of endocrine pancreatic tissue or islet organ forms, the exocrine pancreas commonly diffuses in the mesentery that extends between the bile ducts, blood vessels in the abdomen, intestine, stomach, liver, and gall bladder, and exocrine tissue commonly presents in intrahepatic sites among the teleosts. Islet tissue may be observed in any of those regions, with the exception of intrahepatic sites (for review, see Youson and AlMahrouki). ${ }^{3}$ The islet tissues of ray-finned fish possess four main endocrine cell types: glucagon, insulin, pancreatic polypeptide, and somatostatin. The existence and lack of those endocrine cells are associated with the tissue's history, both ontogenetically and phylogenetically, between the fish., Among the fish, cyclostomes (hagfish, lampreys) are the first species possessing isletlike organs. In hagfish, two cell types are included in the islet tissue, whereas the islet tissue consists of three cell types in adult lampreys. First, the real islet organ containing three or four hormones is formed with cartilagenous fish (shark, ray) and bony fish (telelost and lungfish). ${ }^{5}$ Immunohistochemical studies in the past using antisera mainly raised in mammalian species displayed types of endocrine cells in fish islet organs, such as agnathans (lampreys, hagfish), ${ }^{6-8}$ chondrichthyans, ${ }^{9-12}$ dipnoans (Neoceratodus forstreri, Protopterus aethiopicus, Propterus annectens), ${ }^{13-15}$ holosteans (Amia calva, Lepisosteus osteus), ${ }^{16,17}$ osteoglossomorpha (Osteoglossum bicirrhosum, Scleropages jardini, Pantodon buchholzi, Notopterus chitala, and Gnathonemus petersii), ${ }^{18}$ elopomorpha (Anguilla anguilla), ${ }^{19}$ and euteleosteans. ${ }^{3}$

The Lake Van fish (Alburnus tarichi Güldenstädt, 1814) belongs to the family Cyprinidae and is an endemic fish species
Correspondence: Dr. Burak Kaptaner, University of Van Yuzuncu Yil, Faculty of Science, Department of Biology, 65080 Tuşba/Van, Turkey.

Tel. +90.505 .6747203 - Fax: +90.432 .2251802 .

E-mail: bkaptaner@yahoo.com

Key words: Alburnus tarichi; Lake Van fish; pancreas; histology; immunohistochemistry; endocrine cells.

Funding: This study was partially supported by the Scientific Research Projects Coordination Unit of Van Yuzuncu Yil University under project number FAP-2018-7215.

Conflict of interest: The author declares no conflict of interest.

Received for publication: 4 December 2018. Accepted for publication: 15 February 2019.

This work is licensed under a Creative Commons Attribution-NonCommercial 4.0 International License (CC BY-NC 4.0).

(C) Copyright B. Kaptaner, 2019

Licensee PAGEPress, Italy

European Journal of Histochemistry 2019; 63:2999 doi:10.4081/ejh.2019.2999

to the Lake Van basin, in the eastern Anatolia, Turkey. Lake Van, the biggest soda lake on Earth, possesses water that is highly alkaline $(\mathrm{pH}$ : 9.8; total alkalinity: $153 \mathrm{meq} / \mathrm{L}$ ) and brackish (total salinity: $0.22 \%$ ). Lake Van is solely inhabited by this species of fish, which demonstrates the extreme living environment, in addition to the absence of higher plants in its littoral. In general, living conditions are lethal for fish and invertebrates. Thus, the Lake Van fish has physiological abilities to adapt to Lake Van conditions. Another biologically important feature of the Lake Van fish is that it is an anadromous species and performs annual spawning migration toward the freshwater streams emptying into the lake for reproduction. The reproduction period of the fish begins in middle of April and extends to the middle of July, but most fish pass into freshwater inlets from the highly alkaline and brackish waters of the lake during May. ${ }^{20}$ Cyprinids do not possess a true stomach and they have an expansion at the anterior part of the intestine. ${ }^{1}$ The alimentary canal of the Lake Van fish is composed of buccal cavity, pharynx, esophagus, post-esophageal swelling, and intestine segments, and the pancreas develops in front of the anterior intestine and grows towards the end of the intestine. ${ }^{21}$ There have been many studies in the past elucidating endocrine cells with their regional distributions and relative frequencies in teleost fish; ${ }^{22-28}$ however, the Lake Van fish has not yet been studied. The 
aim of the current work is to first investigate the regional distribution, volume density, and relative frequency in the islets of cells secreting glucagon, insulin, and somatostatin in the pancreas of Lake Van fish using specific antisera against mammalian counterparts.

\section{Materials and Methods}

\section{Fish}

This study comprised examinations of 6 adult Lake Van fish (Alburnus tarichi Güldenstädt, 1814) (fork length: $18-20 \mathrm{~cm}$ and total weight: $80-100 \mathrm{~g}$ ). The professional fishermen who caught the fish from Lake Van $\left(43^{\circ} 13^{\prime} \mathrm{E}, 38^{\circ} 26^{\prime} \mathrm{N}\right)$ during the fishing season (March 2018) provided the study material. The fish used in this study died under natural circumstances. According to the Turkish Ministry of Forestry and Water Affairs regulations, the post mortem use of animal tissues does not require approval of the Animal Experiments Local Ethics Committee (The Official Gazette of Republic of Turkey on February 15, 2014, No. 28914). A decision was also provided for this study by the Animal Experiments Local Ethics Committee of Van Yuzuncu Yil University (decision number: YUHADYEK-2017/11).

\section{Histological procedures}

Immediately after the animals' death, the digestive tract and its associated tissues were carefully dissected. The tissues were then fixed in Bouin's solution and a $10 \%$ concentration of neutral buffered formalin, separately, at $4^{\circ} \mathrm{C}$ for $24 \mathrm{~h}$. Next, they were dehydrated using a graduated ethanol series, and embedded in paraffin. The cross-sections $(5 \mu \mathrm{m}$ thick) from the tissues fixed with Bouin's solution were taken and placed on adhesive-coated slides (Marienfeld GmbH, Lauda-Königshofen, Germany). Xylene was then used to deparaffinize the serial sections, and following rehydration via decreased concentrations of ethanol, hematoxylin and eosin was used for staining. All of the preparations were mounted with Canada balsam, and examined and photographed using a microscope (Leica DMI 6000B model).

\section{Histochemical and immunohisto- chemical procedures}

Tissue sections taken from the Bouin fixed tissue samples were deparaffinized and rehydrated, and then stained with modified aldehyde fuchsin. ${ }^{29}$ For the immunohistochemical staining, a commercial immunohistochemistry kit (EXPOSE Mouse and Rabbit Specific IHC/DAB
Detection IHC Kit, cat. no: ab80436, Abcam, UK) was used according to the kit's protocols. The sections taken from the tissues fixed with neutral buffered formalin were deparaffinized and rehydrated, and then incubated with hydrogen peroxide for $10 \mathrm{~min}$ to inhibit endogenous peroxidase activity. Next, tris-buffered saline (TBS) was used to wash the sections and a 10-min protein block was applied to prevent nonspecific binding. In several previous studies, antisera raised in mouse or rabbit have been successfully used to investigate the endocrine pancreas or digestive tract of different teleost species. ${ }^{27,28,30}$ The sections were then incubated with primary antibodies raised in mammalian species (Table 1) at $4^{\circ} \mathrm{C}$ for $24 \mathrm{~h}$. Rinsing of the sections with TBS was followed by incubation for $10 \mathrm{~min}$ with a complement provided in the kit components and then treated with horseradish peroxidase conjugate. To visualize the peroxidase activity, a substrate-chromogen solution that contained 3,3'-diaminobenzidine was used to incubate the sections for 13 min (until the appearance of a brown color), at which time, double-distilled water was used to wash them. Mayer's hematoxylin was used to perform the counterstaining. Next, gradual ethanol concentrations of $95 \%$ and $100 \%$ were used to treat the slides, and cover slips were used to cover them, following sealing with Canada balsam (Merck, Germany). Negative and positive control slides were used to test the specificity of the antibodies. In the negative control slides, TBS was added instead of a primary antibody. The sections taken from the archived rat pancreas, which was embedded in paraffin, were used as positive controls for each of the staining experiments. The examinations, as well as photographs, of the slides were done using a Leica DMI 6000B microscope.

\section{Cell counting}

The volume density of each immunoreactive (IR) endocrine cell type within the principle and secondary islets was estimated by cell counting using ImageJ 1.46 software, which is freely downloadable (https://imagej.nih.gov/ij/download.html). Photographs of 10 randomly selected principle and secondary islets from immunestained sections were captured at $20 \times$ magnification using a Leica Digital DFC490 camera (Leica Microsystems CMS GmbH,
Wetzlar, Germany) connected to a Leica DMI 6000B model microscope. Immunopositive and -negative endocrine cells distributed in the islets were counted using the cell counter plugin of ImageJ 1.46 software (https://imagej.nih.gov/ij/plugins/cellcounter.html). Between 70 and 550 endocrine cells for the principle islets and 20 to 70 endocrine cells for the secondary islets were counted. Next, the percentage of immune-positive endocrine cells to each antibody was calculated among the total endocrine cell population.

\section{Relative frequency in pancreatic regions}

The distribution of immune-positive cells was evaluated in four pancreatic regions, including the principle islets, secondary islets, exocrine pancreas, and pancreatic ducts, according to the method of Kong et al. with small modifications. ${ }^{28}$ The pancreatic islets were further subdivided into central and peripheral regions, whereas the pancreatic ducts were subdivided into ductal epithelium and subepithelial connective tissue. The relative frequency for each encdocrine cell type was scored and classified into five categories: -, not detected; \pm , rare; +, small number; ++ , moderate; +++ , numerous.

\section{Statistical analyses}

Statistical analysis of the data from the cell counts was performed using the Statistical Package for the Social Sciences software, version 16.0 for Windows. For a comparison of the differences between two islet groups, the student's t unpaired test was utilized and the mean \pm standard error of the mean (SE) were used to express the results. $\mathrm{P}<0.05$ was considered statistically significant.

\section{Results}

The pancreas tissue was observed to be surrounded by adipose tissue that were adjacent to liver, gall bladder, or extrahepatic bile duct, or dispersed in adipose tissue ranked among coils of post-esophageal swelling and intestinal parts of the digestive tract. It was comprised of exocrine and endocrine units. The exocrine pancreas consisted of glandular acini, ducts, vessels, and adipocytes (Figure 1 A,B). The endocrine

Table 1. Antibodies used in the present study.

\begin{tabular}{lccc}
\hline Antibody & Product code & Source & Dilution \\
Polyclonal rabbit anti-insulin & ab210560 & Abcam & $1: 25$ \\
Monoclonal mouse anti-glucagon (ICACLS) & $14-9743-80$ & Invitrogen & $1: 25$ \\
\hline Monoclonal mouse anti-Somatostatin (ICDCLS) & $14-9751-80$ & Invitrogen & $1: 25$ \\
\hline
\end{tabular}


pancreas or islet tissue was distributed in the exocrine pancreas, and composed of large principle islets and small secondary islets. Principal islets diffusely existed in the exocrine pancreas and were irregular, oval, or round in shape, and in small quantities. They were observed to be located mainly in the exocrine pancreas tissue, which was surrounded by adipose tissue that enclosed the gall bladder, located between the liver and dorsal side of the post-esophageal swelling (Figure $1 \mathrm{~A}, \mathrm{~B}$ ). The small secondary islets were oval or round in shape and scattered throughout the exocrine pancreas, and were more in point of numbers than the principal islets (Figure 2A). The exocrine pancreas was also observed around the bile ducts entering the liver; however, the endocrine cells or islets could not be detected in those portions of the exocrine pancreas (Figure 2B). After modified aldehyde fuchsin staining, the beta cells were moderately stained with violet. It was observed that those round- or polygonal-shaped cells were major cell types in the principal and secondary islets, and were determined to be situated throughout the islets, most commonly in the central region, and a small number were in the periphery region of the principal (Figure 3A) and secondary (Figure $3 \mathrm{~B}, \mathrm{C}$ ) islets.

In the present study, three endocrine cell types were demonstrated with immunohistochemistry using antibodies against mammalian insulin, glucagon, and somatostatin in the pancreatic islets, ducts, and exocrine regions. The volume density of each IR endocrine cell within the principle and secondary islets were quantified by counting. As seen in Table 2, insulin-, glucagon- and somatostatin-IR cells were counted at about $54 \%, 28 \%$, and $11 \%$, respectively, in the principle islets, while they were counted at about $52 \%, 27 \%$, and $13 \%$ in the secondary islets, respectively. Significant differences were not found between any of the IR cell types in the principle and secondary islets.

The regional distribution and relative abundance of the immunoreactive endocrine cells in the islets and different pancreatic regions are presented in Tables 3 and 4, respectively. Insulin-IR cells were generally round and oval in shape, while a small number were spindle in shape, in the islets and possessed short cytoplasmic processes. The distribution of insulin-IR cells well corresponded to observations from the aldehyde fuchsin staining and those cells were determined to be localize throughout the islets. Insulin-IR cells were commonly observed in the central region and a small number in the peripheral areas were intermingled with other endocrine cells in the principle islets (Figure 4 A,B). A similar trend in the distribution of those
Table 2. Volume densities of the endocrine cells in the principle and secondary islets of A. tarichi.

\begin{tabular}{lcc}
\hline Immunoreactive cell type & Principle islets & Secondary islets \\
Insulin & $54.03 \pm 2.50 \%$ & $52.08 \pm 2.05 \%$ \\
Glucagon & $28.70 \pm 0.94 \%$ & $27.31 \pm 3.15 \%$ \\
\hline Somatostatin & $11.37 \pm 0.98 \%$ & $13.61 \pm 1.47 \%$ \\
Other & $5.9 \%$ & $7 \%$ \\
\hline Total & $100 \%$ & $100 \%$ \\
\hline
\end{tabular}

Values are mean \pm SE.

Table 3. Regional distribution and relative abundance of the immunoreactive endocrine cells in the primary and secondary islets of $A$. tarichi.

\begin{tabular}{lcccccc} 
& \multicolumn{3}{c}{ Principal islets } & \multicolumn{3}{c}{ Secondary islets } \\
Antibodies & Peripheral & Central & Throughout & Peripheral & Central & Throughout \\
Insulin & + & +++ & +++ & + & +++ & +++ \\
Glucagon & ++ & + & ++ & ++ & + & ++ \\
\hline Somatostatin & + & + & + & + & + & +
\end{tabular}

-, not detected; \pm , rare; +, small number; ++ , moderate; +++ , numerous.

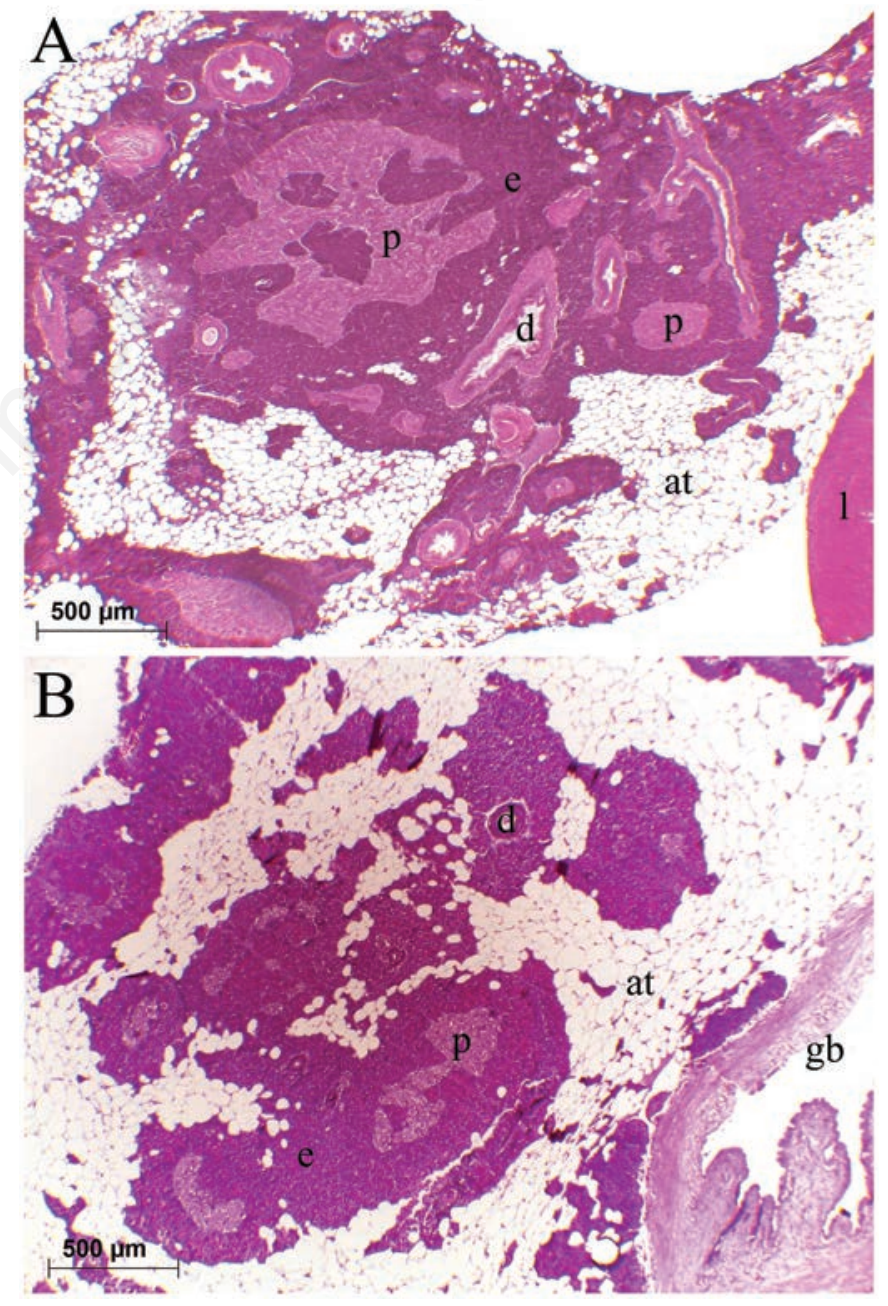

Figure 1. Distribution of the pancreas next to the liver (A) and gall bladder (B). The exocrine pancreas (e) was surrounded by adipose tissue (at). Pale stained principal islets (p) with hematoxylin and eosin were dispersed in the exocrine pancreas: liver (l), gall bladder (gb), pancreatic duct (d). 
cells was also observed in the secondary islets (Figure 4C). Insulin-IR cells were also found in the exocrine parenchyma, either individually or with two or three grouped together (Figure $4 \mathrm{D}, \mathrm{E}$ ). Those cells were found around the exocrine ducts, either individually or with two or three grouped together (Figure $4 \mathrm{~F}, \mathrm{G}$ ), and were rarely noted in the epithelium (Figure 4G) or subepithelial connective tissue of the exocrine ducts (Figure 4H).

Round-, triangular-, or spindle-shaped glucagon-IR cells were observed to be situated moderately on the periphery of the principle islets. Additionally, they were rarely determined in the central region as scattered or intermingled with other endocrine cells, especially with insulin IRcells (Figure 5 A,B). A similar trend in the distribution of those cells was also observed in the secondary islets (Figure $5 \mathrm{C}, \mathrm{D}$ ). Glucagon-IR cells were rarely detected in the exocrine parenchyma (Figure 5E). They were observed to be placed around the exocrine ducts, either individually or with two or three grouped together (Figure 5 F,G). Occasionally, an observation was made of Glucagon-IR cells among the pancreatic duct epithelium (Figure $5 \mathrm{G}, \mathrm{H}$ ) and in the sub-epithelial connective tissue on rare occasions (Figure 5I).

The somatostatin-IR cells were round, triangular, or spindle in shape, with cytoplasmic processes. As observed with the glucagon-IR cells, somatostatin-IR cells were observed in both the periphery and center of the principle islets in small numbers (Figure $6 \mathrm{~A}, \mathrm{~B}$ ) intermingled with other endocrine cells, sometimes constituting small clusters. The same trend was also observed in the secondary islets (Figure 6 C,D). Somatostatin-IR cells were rarely observed among the epithelium (Figure 6E) and connective tissue of the exocrine ducts (Figure 6F). The cells were rarely detected in the exocrine parenchyma (Figure 6G). Those cells were also detected to be situated around the ducts individually or in the exocrine pancreas, either individually or with two or three grouped together (Figure $6 \mathrm{H})$.

\section{Discussion}

In the present study, histological examinations displayed that the islet organs were dispersed within the exocrine pancreas surrounded by adipose tissue. Principal islets were observed to be localized mainly in the exocrine pancreas tissue enclosing the gall bladder and the small secondary islets were sporadically spread out amid the exocrine pancreas. Youson and Al-Mahrouki opined that Salmoniformes displays an intermedi-
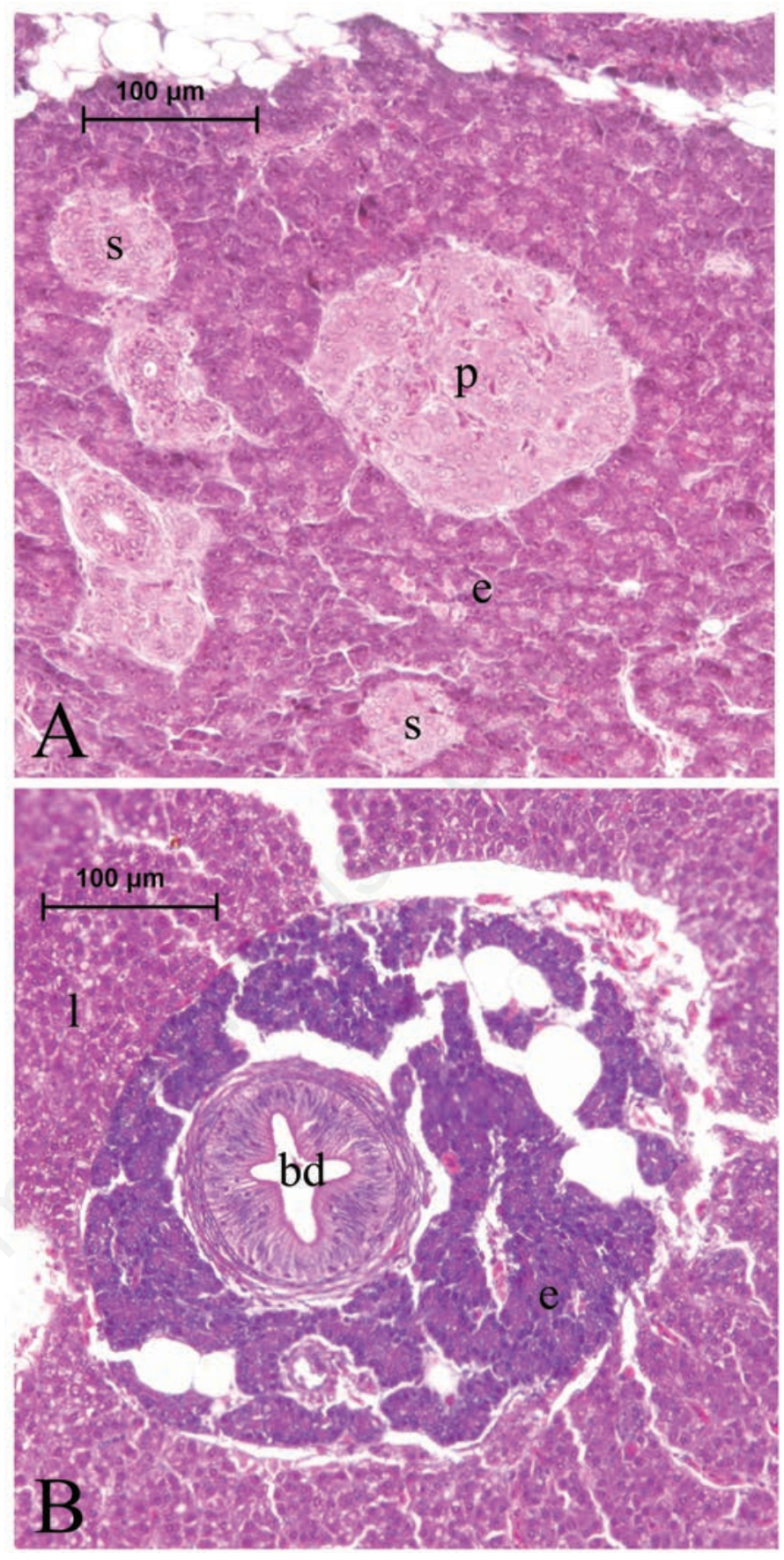

Figure 2. A principal islet (p) and small secondary islets (s) within the exocrine portion of the pancreas (A). Exocrine pancreas (e) surrounding the bile duct (bd) within the liver (l) parenchyma (B).

Table 4. Regional distribution and relative abundance of the immunoreactive endocrine cells in the ducts and exocrine regions of the pancreas of $A$. tarichi.

\begin{tabular}{|c|c|c|c|}
\hline & \multicolumn{2}{|c|}{ Pancreatic ducts } & \multirow[t]{2}{*}{ Exocrine pancreas } \\
\hline Antibodies & Epithelium & Subepithelium & \\
\hline Insulin & \pm & \pm & + \\
\hline Glucagon & + & \pm & \pm \\
\hline Somatostatin & \pm & \pm & \pm \\
\hline
\end{tabular}

- , not detected; \pm , rare; +, small number; ++ , moderate; +++ , numerous. 
ate phylogenetic development of principal islets and that the islets aggregate into a specific site of the exocrine pancreas in coho salmon and rainbow trout, which is called the islet organ or principal body. Although small islets are dispersed throughout the other parts of the pancreas, the intrahepatic pancreas tissue is generally devoid of islets. The authors also expressed that this description was also found in other generalized euteleosts, cyprinids, and catfish. Thus, the pattern of islet distribution in A. tarichi resembles that in salmonids. ${ }^{3}$

The distribution of the insulin-IR cells well corresponded to that of the aldehyde fuchsin-positive cells in the present study, consistent with other research. ${ }^{15,23,26,31}$ According to the volume density analyses, the principal islets contained $54 \%$ insulin-, $28 \%$ glucagon-, and $11 \%$ somatostatin-IR cells, while the secondary islets consisted of $57 \%$ insulin-, $27 \%$ glucagon-, and 13\% somatostatin-IR cells. Significant differences were not noted between those islets in terms of the cell type density. As cited by Yang et al., Falkmer resumed frequencies of different endocrine cell types in the islets of generic teleosts using the data from different researchers and stated that the percentages of insulin-, somatostatin-, glucagon-, and peptide tyrosine-tyrosine (PYY)-related IR cells were approximately 30-50, 25-40, 15-20, and 20-30, respectively. ${ }^{26,32}$ However, insulin-IR reactive cells were reported as slightly more than $50 \%$ of the islet cells by the counting aldehyde fuchsinophil cells. Our results, which are the first for A. tarichi, were found to be similar to that of other teleost fish. On the other hand, $5.9 \%$ of the endocrine cells in the principal islets and $7.0 \%$ of the cells in the secondary islets were not stained by immunohistochemistry. In this study, we could not perform immunohistochemical staining using an antiserum against pancreatic polypeptide, thus we supposed that the remaining percentage of islet cells represented the pancreatic polypeptide-producing cells, which was previously reported in other teleost species. . $^{16,18,23,24,26-28,31,33}$

The results of the present study revealed that insulin-IR cells were rarely localized in the peripheral and mainly in the central regions of the islets. In the islets, the insulin-IR cell central localization has been described in previous studies conducted on numerous teleosteans: rainbow trout (Salmo gairdneri) ${ }^{23}$ Barbus conchonius, ${ }^{24}$ ratfish (Chimaera monstrosa), ${ }^{10}$ lungfish (Neoceratodus forstreri), ${ }^{13}$ sea bass (Dicentrarchus labrax), ${ }^{34}$ Propterus annectens, ${ }^{15}$ gar (Lepisosteus osseus), ${ }^{16}$ five species of osteoglossomorpha, ${ }^{18}$ bowfin (Amia calva), ${ }^{14}$ Silurus asotus and Siniperca scherzeri, ${ }^{27}$ carp (Cyprinus carpio), ${ }^{28}$ and
Amblopites rupestris. ${ }^{4}$ In some teleost species, insulin-IR cells were determined in the periphery of the islets, such as in anglerfish (Lophius americanus), ${ }^{35}$ Mugil auratus, and Mugil saliens. ${ }^{36}$ In a marine teleost, Fugu rubripes rubripes, aldehyde fuchsinpositive beta cells were distributed as small groups throughout the islets, ${ }^{22}$ and insulinIR cells occurred in the peripheral and central regions of the islets of flatfish (Paralichtys olivaceus). ${ }^{31}$ Thus, it seems that the distribution pattern of insulin-IR cells in A. tarichi is consistent with previous observations from other teleosts.

Glucagon-IR cells distributed throughout the islets in $A$. tarichi are commonly in peripheral sites rather than central regions. It has been reported that Glucagon-IR cells are generally localized in the peripheral sites of the islets of fish, such as rainbow trout (Salmo gairdneri), ${ }^{23}$ flatfish (Paralichtys olivaceus), ${ }^{31}$ sea bass (Dicentrarchus labrax), ${ }^{37}$ Propterus aethiopicus, ${ }^{14} \quad$ Propterus annectens, ${ }^{15}$ gar (Lepisosteus osseus), ${ }^{16}$ bowfin (Amia calva), ${ }^{17}$ Amblopites rupestris, ${ }^{4}$ Silurus asotus, and Siniperca scherzeri. ${ }^{27}$ In Osteoglossomorpha, an ancient teleostean group, Glucagon-IR cells were observed in a peripheral thick rim in the islets of Osteoglossum bicirrhosum and Gnathonemus petersii; however, in Scleropages jardini, Pantodon buchholzi, and Notopterus chitala, the cells were scattered throughout the islets in addition to the peripheral cells. ${ }^{18}$ In Barbus conchonius, glucagonIR cells were located in the periphery and occurred in the cell cords in the central part of the principal islet, while they were mainly confined to the peripheral region in smaller islets. ${ }^{24}$ Glucagon-IR cells were localized in the central and peripheral regions of both the principal and secondary islets of carp (Cyprinus carpio). ${ }^{28}$ Thus, the distribution of glucagon-IR cells in the central and peripheral regions in islets seems to be a pattern pertaining to species of the family Cyprinidae.
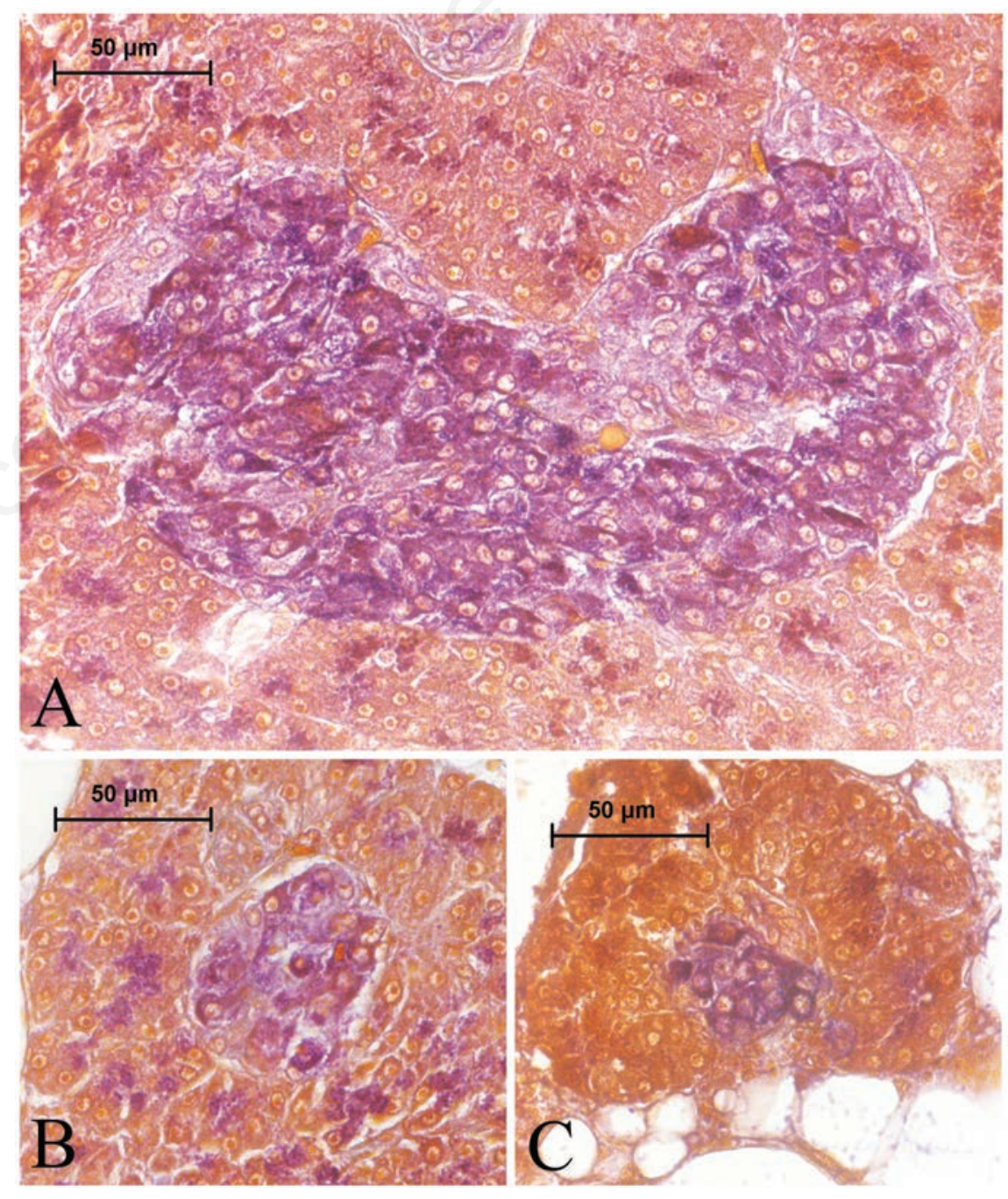

Figure 3. Aldehyde fuchsin-stained principal (A) and secondary $(B, C)$ islets. Aldehyde fuchsin-positive beta cells were stained violet and distributed throughout the islets. 
In A. tarichi, somatostatin-IR cells were found throughout the islets, intermingled with other endocrine cells. Similarly, Yoshida et al. ${ }^{31}$ the occurrence of rounded somatostatin-IR cells in the peripheral regions and irregular-shaped somatostatinIR cells dispersed in the central region in the principal islet of flatfish (Paralichtys olivaceus), whereas somatostatin-IR cells were distributed through the smaller islets. Somatostatin-IR cells were located in both the peripheral and central region of the islets of carp (Cyprinus carpio). ${ }^{28}$ In Silurus asotus, somatostatin-IR cells were localized in the central region of the islets, mixed with insulin-IR cells and at the peripheral region with lower frequency; however, somatostatin-IR cells were localized only in the peripheral region of the islets in Siniperca scherzeri. ${ }^{27}$ On the other hand, somatostatin-IR cells were detected between insulin-IR cells, which were located in the central region of the islets of Barbus conchonius. ${ }^{24}$ In teleost fish, there are two types of somatostatin-producing cells. Apart from somatostatin-14-IR cells, a type of somatostatin-producing cell found in all vertebrates, which are closely associated with insulin-IR cells, a second type of somatostatin-producing cell that possesses 22-28 amino acid residues is peculiar to teleost fish. ${ }^{26,38-40}$ In Sparus aurata, somatostatin-14-IR cells were located in the central region of the islets between insulin-IR cells whereas salmon somatostatin-25-IR cells were observed in the periphery of the islet

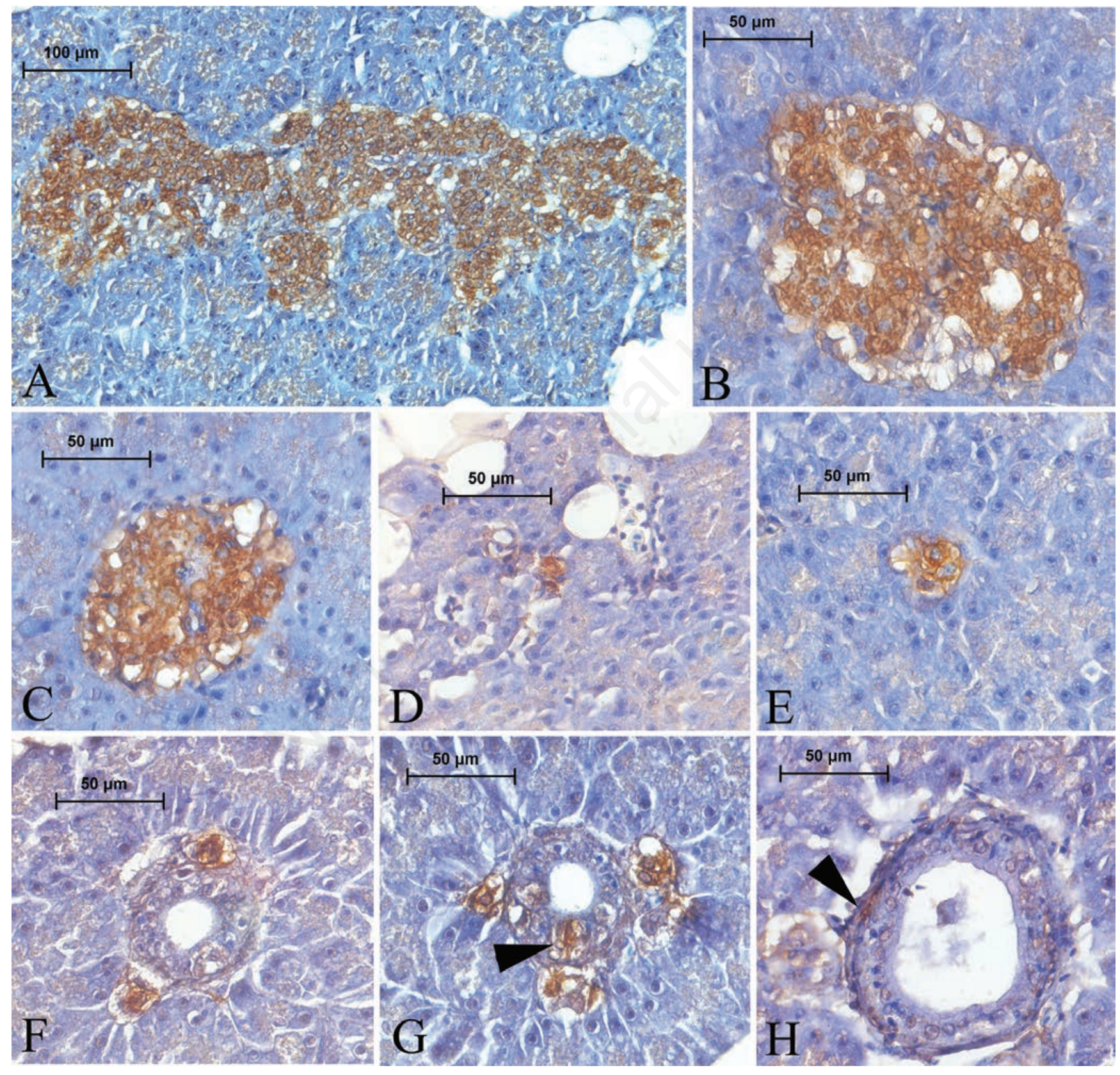

Figure 4. Insulin-IR cells in the pancreas of Lake Van fish. Insulin-IR cells, which are a major endocrine cell type, distributed throughout both the principal $(A, B)$ and secondary $(C)$ islets. Insulin-IR cells were observed in the exocrine area, either individually or with two or three grouped together $(\mathrm{D}, \mathrm{E})$. Those cells were found around the exocrine ducts, either individually or with two or three grouped together (F, G) and noted among the ductus epithelium (G) (arrowhead) or in the subepithelial connective tissue of the ducts (H) (arrowhead). 
among the glucagon-IR cells. ${ }^{39}$ Somatostatin-14-IR cells were found throughout the islets of Amblopites rupestris, whereas somatostatin-25-IR cells were confined to the peripheral region. In goldeye (Hiodon alosoides), somatostatin14-IR and somatostatin-25-IR cells were localized to the same peripheral islet cells. ${ }^{4}$ Somatostatin-14-IR was closely associated with insulin-IR cells and somatostatin-25IR cells extending into the islet periphery, and surrounded by clusters of insulin-IR and somatostatin-14-IR cells in the islets of tilapia (Oreochromis niloticus). ${ }^{26}$ Somatostatin-IR cells were observed in the peripheral and central regions of the islets in Propterus annectens. ${ }^{15}$ In bowfin (Amia calva), somatostatin-14-IR and somato-
statin-25-IR cells were diffusely distributed throughout the islets. ${ }^{17}$ In gar (Lepisosteus osseus), somatostatin-IR cells were dispersed mainly in the central region of the islet with insulin IR cells and a few were in the peripheral sites. ${ }^{16}$ It is understood from the above mentioned studies that the somatostatin-IR cell distribution in islets may vary depending on the fish species;
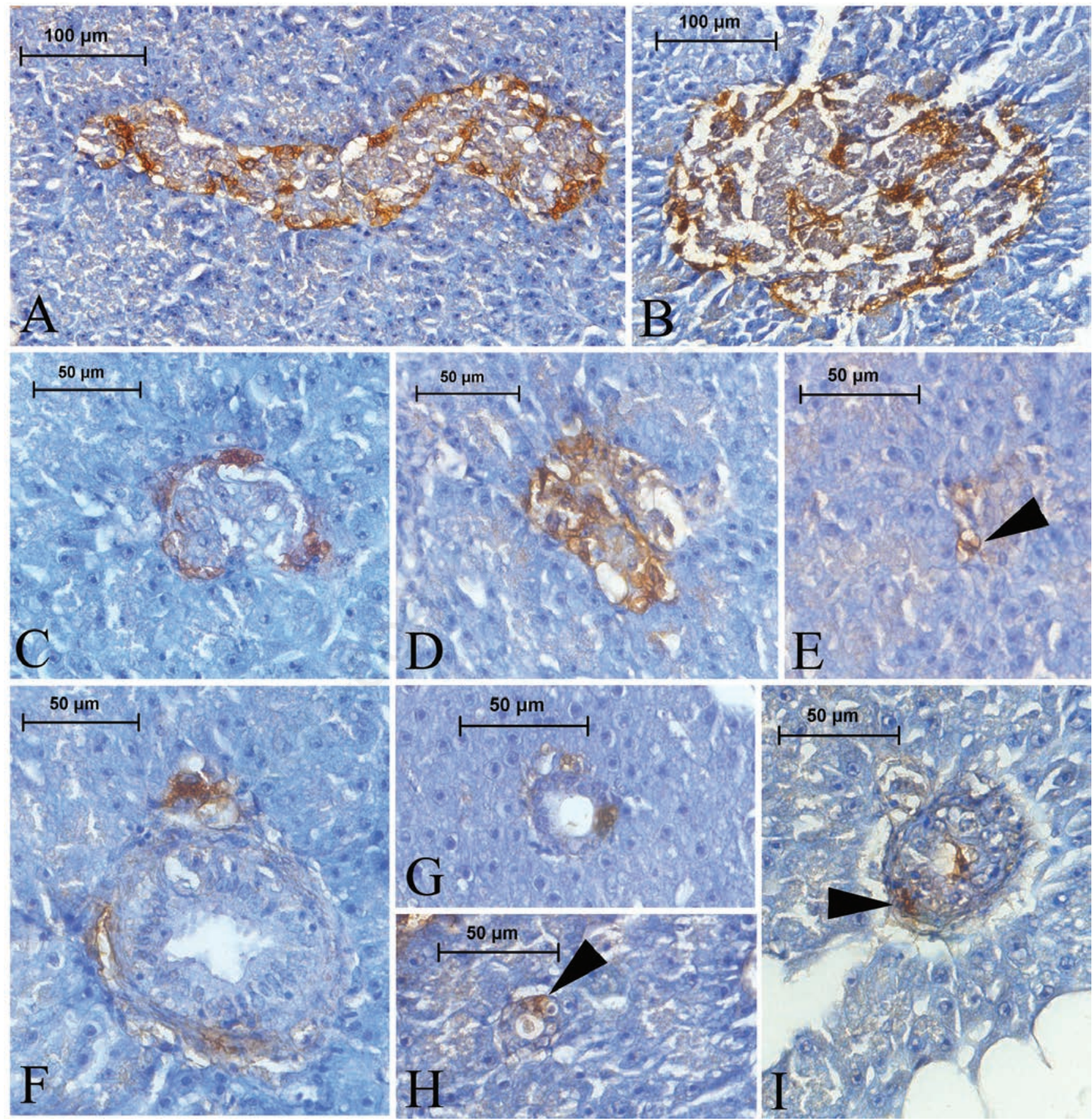

Figure 5. Glucagon-IR cells in the pancreas of Lake Van fish. Glucagon-IR cells were detected in both the periphery and central regions of the principal (A, B) and secondary (C,D) islets. Those cells were rarely observed in the exocrine area (E) (arrowhead). Glucagon-IR cells were found around the exocrine ducts, either individually or with two or three grouped together (F), and noted among the ductus epithelium (G,H) (arrowhead) or in the subepithelial connective tissue of the ducts (I) (arrowhead). 
thus, these cells are arranged in the islets of $A$. tarichi in a similar manner to that reported in the islets of most fish species.

Insulin-, glucagon-, and somatostatinIR cells were also observed in the exocrine parenchyma, ductus epithelium, and subepithelial connective tissue of the exocrine ducts with lower frequency in this study. Although the presence of endocrine cells in those regions was commonly reported in higher vertebrates, ${ }^{41,42}$ similar observations were reported in some fish species. Immunoreactive cells were detected among the exocrine acini; however, no immunore- activity was noted in the ducts of the exocrine pancreas of the five species of osteoglossomorha. ${ }^{18}$ Some of the pancreatic duct cells displayed insulin, glucagon, and somatostatin immunoreactivities and some endocrine cells were scattered in the exocrine parenchyma in the ray (Dasyatis
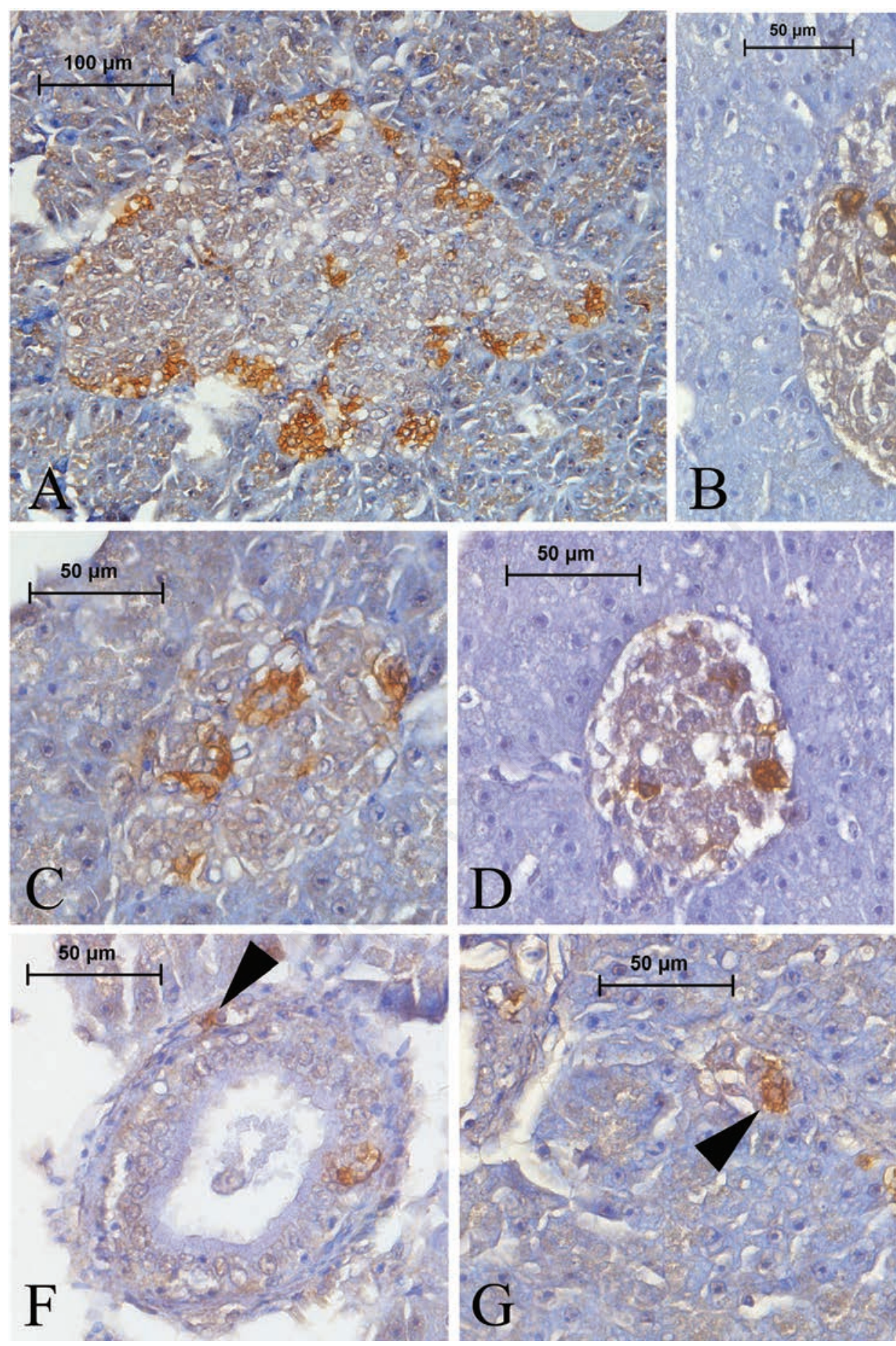
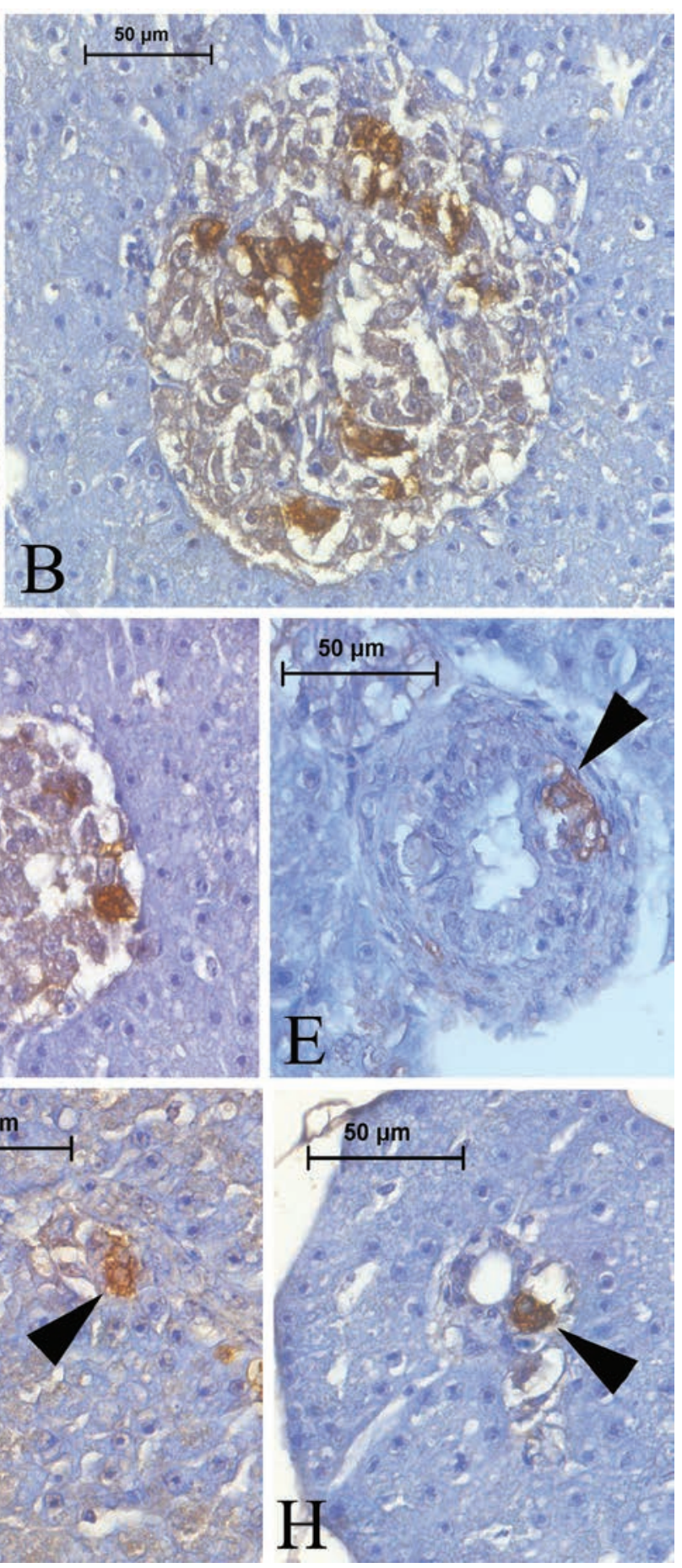

Figure 6. Somatostatin-IR cells in the pancreas of Lake Van fish. These cells were detected in both the periphery and central regions of the principal (A, B) and secondary (C, D) islets. Somatostatin-IR cells were found among the ductus epithelium (E) (arrowhead) or in the subepithelial connective tissue of the ducts (F) (arrowhead). Those cells were rarely observed in the exocrine area (G) (arrowhead). Somatostatin-IR cells were found around the exocrine ducts, either individually or with two or three grouped together $(\mathrm{H})(\mathrm{arrowhead})$. 
akajei). ${ }^{9}$ Ontogeny studies on sea bass (Dicentrarchus labrax) reported endocrine cells among the pancreatic ductus epithelium. ${ }^{43,44}$ The presence of somatostatin immunoreactivity was detected in the epithelial and connective tissue of pancreatic ducts in gar (Lepisosteus osseus). ${ }^{16}$ Glucagon-IR cells among the exocrine acini of bowfin (Amia calva) were also determined. ${ }^{17}$ In accordance with this study, Lee et al. (2002) also reported insulin-, glucagon-, and somatostatin-IR cells in the subepithelial and epithelial regions of the ducts and exocrine regions of carp (Cyprinus carpio) pancreas. ${ }^{28}$

In conclusion, the pattern of islet distribution in $A$. tarichi shows similarity to that observed in Salmonids. The regional distribution, volume density, and relative frequency of glucagon-, insulin-, and somatostatin-IR cells in A. tarichi are similar to those reported in other teleostean fish species. Additionally, the pattern of glucagon distribution in the islets is more consistent with that of Cyprinidae species. The 3 types of endocrine cells were also detected in the subepithelial and epithelial regions of the ducts and exocrine regions, as was reported in higher vertebrates that this finding is a species-dependent characteristic of $A$. tarich $i$ which is a stomachless teleost fish.

\section{References}

1. Strüsmann CA, Takashima F. Digestive system. In: Takashima F, Hibiya $\mathrm{T}$ (eds.) An atlas of fish histology: Normal and pathological features. KodanshaGustav Fischer Verlag, Stuttgart, 1995; p. 88-115.

2. Genten F, Terwinghe E, Danguy A. Endocrine glands. In: Atlas of fish histology. Science Publishers, Enfield, NH, USA, 2009; p. 141-58.

3. Youson JH, Al-Mahrouki AA. Ontogenetic and phylogenetic development of the endocrine pancreas (islet organ) in fishes. Gen Comp Endocrinol 1999;116:303-35.

4. Youson JH, Al-Mahrouki AA, Amemiya Y, Graham LC, Montpetit CJ, Irwin DM. The fish endocrine pancreas: review, new data, and future research directions in ontogeny and phylogeny. Gen Comp Endocrinol 2006;148:105-15.

5. Heller RS. The Comparative Anatomy of Islets. In: Islam MS (ed.) The islets of Langerhans. Springer, Dordrecht, 2010; 21-37.

6. Cheung R, Andrews PC, Plisetskaya EM., Youson JH. Immunoreactivity to peptides belonging to the pancreatic polypeptide family (NPY, aPY, PP,
PYY) and to glucagon-like peptide in the endocrine pancreas and anterior intestine of adult lampreys, Petromyzon marinus: An immunohistochemical study. Gen Comp Endocrinol 1991;81: 51-63.

7. Cheung R, Ferreira LCG, Youson JH. Distribution of two forms of somatostatin and peptides belonging to the pancreatic polypeptide family in tissues of larval lampreys, Petromyzon marinus L.: An immunohistochemical study. Gen Comp Endocrinol 1991;82:93-102.

8. Youson JH, Potter IC. An immunohistochemical study of enteropancreatic endocrine cells in larvae and juveniles of the southern hemisphere lampreys, Geotria australis and Mordacia mordax. Gen Comp Endocrinol 1993;92:151-67.

9. Sekine Y, Yui R. Immunohistochemical study of the pancreatic endocrine cells of the ray, Dasyatis akajei. Arch Histol Jap 1981;44:95-101.

10. Yui R, Fujita T. Immunocytochemical studies on the pancreatic islets of the ratfish Chimaera monstrosa. Arch Histol Jap 1986;49:369-77.

11. Jönsson AC. Endocrine cells with gastrin/cholecystokinin-like immunoreactivity in the pancreas of the spiny dogfish, Squalus acanthias. Regul Pept 1995;59:67-78.

12. Chiba, A., Honma, Y. and Oka, S. Ontogenetic development of neuropeptide Y-like-immunoreactive cells in the gastroenteropancreatic endocrine system of the dogfish. Cell Tissue Res 1995;282:33-40.

13. Hansen GN, Bente LH, Peer NJ. Insulinglucagonand somatostatin-like immunoreactivity in the endocrine pancreas of the lungfish, Neoceratodus forsteri. Cell Tissue Res 1987;248:181-5.

14. Scheuermann DW, Adriaensen D, Timmermans JP, De Groodt-Lasseel MH. Immunohistochemical localization of polypeptide hormones in pancreatic endocrine cells of a dipnoan fish, Protopterus aethiopicus. Acta Histochem 1991;91:185-92.

15. Tagliafierro G, Carlini M, Faraldi G, Morescalchi AM, Putti R, Della Rossa A, Fasulo S, Mauceri A. Immunocytochemical detection of islet hormones in the digestive system of Protopterus annectens. Gen Comp Endocrinol 1996;102:288-98.

16. Groff KE, Youson JH. An immunohistochemical study of the endocrine cells within the pancreas, intestine, and stomach of the gar (Lepisosteus osseus L.). Gen Comp Endocrinol 1997;106:1-16.

17. Youson JH, Al-Mahrouki AA, Naumovski D, Conlon JM. The endocrine cells in the gastroenteropan- creatic system of the bowfin, Amia calva L.: an immunohistochemical, ultrastructural, and immunocytochemical analysis. J Morphol 2001;250:20824.

18. Al-Mahrouki AA, Youson JH. Immunohistochemical studies of the endocrine cells within the gastroentero-pancreatic system of Osteoglossomorpha, an ancient teleostean group. Gen Comp Endocrinol 1998;110:125-39.

19. L'Hermite A, Ferrano R, Dubois MP, Andersen AC. Detection of endocrine cells by immunofluorescence method in the gastroenteropancreatic system of the adult eel, glass eel, and leptocephalic larva (Anguilla anguilla L.). Gen Comp Endocrinol 1985;58:347-59.

20. Danulat E, Selcuk B. Life history and environmental conditions of the anadromous Chalcalburnus tarichi (Cyprinidae) in the highly alkaline Lake Van, Eastern Anatolia, Turkey. Arch Hydrobiol 1992;126:105-25.

21. Ünal G, Çetinkaya O, Kankaya E, Elp M. Histological study of the organogenesis of the digestive system and swim bladder of the Chalcalburnus tarichi Pallas, 1811 (Cyprinidae). Turk J Zool 2001;25:217-28.

22. Kobayashi K, Shibasaki S, Takahashi Y. Light and electron microscopic study on the endocrine cells of the pancreas in a marine teleost, Fugu rubripes rubripes. Cell Tissue Res 1976;174:161-82.

23. Wagner GF, McKeown BA. Immunocytochemical localization of hormone-producing cells within the pancreatic islets of the rainbow trout (Salmo gairdneri). Cell Tissue Res 1981;221:181-92.

24. Rombout JHWM, Taverne-Thiele JJ. An immunocytochemical and electronmicroscopical study of endocrine cells in the gut and pancreas of a stomachless teleost fish, Barbus conchonius (Cyprinidae). Cell Tissue Res 1982; 227:577-93.

25. Rombout IHWM, Van der Grinten CPM, Binkhorst FP, Taverne-Thiele JJ, Schooneveld, H. Immunocytochemical identification and localization of peptide hormones in the gastro-entero-pancreatic (GEP) endocrine system of the mouse and a stomachless fish, Barbus conchonius. Histochemistry 1986;84: 471-83.

26. Yang H, Morrison CM, Conlon JM, Laybolt K, Wright Jr JR. Immunocytochemical characterization of the pancreatic islet cells of the Nile Tilapia (Oreochromis niloticus). Gen Comp Endocrinol 1999;114:47-56.

27. Lee JH, Ku SK, Park KD, Lee HS. 
Comparative study of endocrine cells in the principal pancreatic islets of two teleosts, Silurus asotus (Siluridae) and Siniperca scherzeri (Centropomidae). J Vet Sci 2001;2:75-80.

28. Kong HS, Lee JH, Park KD, Ku SK, Lee HS. Immunohistochemical study of the endocrine cells in the pancreas of the carp, Cyprinus carpio (Cyprinidae). J Vet Sci 2002;3:303-14.

29. Halmi NS. Differentiation of two types of basophils in the adenohypophysis of the rat and the mouse. Stain Technol 1952;27:61-4.

30. Vieira-Lopes DA, Pinheiro NL, Sales A, Ventura A, Araújo FG, Gomes ID, Nascimento AA. Immunohistochemical study of the digestive tract of Oligosarcus hepsetus. World J Gastroenterol 2013;19:1919-29.

31. Yoshida K, Iwanaga T, Fujita T. Gastroentero-pancreatic (GEP) endocrine system of the flatfish, Paralichtys olivaceus: an immunocytochemical study. Arch Histol Jap 1983;46:259-66.

32. Falkmer S. Comparative morphology of pancreatic islets in animals. In: Volk BW, Arquilla ER (eds.) The diabetic pancreas. Plenum, New York, 1985; p. 17-52.

33. Van Noorden S, Patent GJ. Localization of pancreatic polypeptide (PP)-like immunoreactivity in the pancreatic islets of some teleost fishes. Cell Tissue
Res 1978;188:521-25.

34. Lozano MT, Ayala AG, Abad ME, Agulleiro B. Pancreatic endocrine cells in sea bass (Dicentrarchus labrax L.): II. Immunocytochemical study of insulin and somatostatin peptides. Gen Comp Endocrinol 1991;81:198-206.

35. Johnson DE, Torrence JL, Elde RP, Bauer GE, Noe BD, Fletcher DJ.. Immunohistochemical localization of somatostatin, insulin and glucagon in the principal islets of the anglerfish (Lophius americanus) and the channel catfish (Ictalurus punctata). Am J Anat 1976;147:119-24.

36. Lozano MT, Agulleiro B. Immunocytochemical and ultrastructural study of the endocrine pancreas of Mugil auratus and Mugil saliens L. (Teleostei). J Submicrosc Cytol 1986;18:85-98.

37. Beccaria C, Diaz JP, Gabrion J, Connes R.. Maturation of the endocrine pancreas in the sea bass, Dicentrarchus labrax L. (Teleostei): An immunocytochemical and ultrastructural study: I. Glucagon-producing cells. Gen Comp Endocrinol 1990;78:80-92.

38. Nozaki M, Miyata K, Oota Y, Gorbman A, Plisetskaya EM. Colocalization of glucagon-like peptide and glucagon immunoreactivities in pancreatic islets and intestine of salmonids. Cell Tissue Res 1988;253:371-5.

39. Plisetskaya EM. Recent studies of fish pancreatic hormones: Selected topics. Zool Sci 1990;7:335-53.

40. Abad ME, Garcia Ayala A, Lozano MT, Agulleiro B. Somatostatin 14- and somatostatin 25-like peptides in pancreatic endocrine cells of Sparus auratus (Teleost): A light and electron microscopic immunocytochemical study. Gen Comp Endocrinol 1992;86:445-52.

41. Wieczorek G, Pospischil A, Perentes E. A comparative immunohistochemical study of pancreatic islets in laboratory animals (rats, dogs, minipigs, nonhuman primates). Exp Toxicol Pathol 1998;50:151-72.

42. Karaca T, Kara A, Şimşek N, Uslu S, Tekiner D, Yörük, M. Immunohistochemical distribution of glucagon-, insulin-, somatostatin-, gastrin-, and serotonin-containing cells in the pancreas of the Van cat. Turk J Vet Anim Sci 2014;38:304-11.

43. Hernandez MPG, Agulleiro B. Ontogeny of the endocrine pancreas in sea bass (Dicentrarchus labrax): An immunocytochemical study. Cell Tissue Res 1992;270:339-52.

44. Hernandez MPG, Lozano MT, Agulleiro B. Ontogeny of some endocrine cells of the digestive tract in sea bass (Dicentrarchus labrax): An immunocytochemical study. Cell Tissue Res 1994;277:373-83. 